Canadian University Music Review

Revue de musique des universités canadiennes

\title{
Articulations of Locality: Portraits and Narratives from the Toronto-Cuban Musicscape
}

\section{Annemarie Gallaugher}

Volume 19, numéro 2, 1999

Canadian Perspectives in Ethnomusicology

Perspectives canadiennes en ethnomusicologie

URI : https://id.erudit.org/iderudit/1014451ar

DOI : https://doi.org/10.7202/1014451ar

Aller au sommaire du numéro

Éditeur(s)

Canadian University Music Society / Société de musique des universités canadiennes

\section{ISSN}

0710-0353 (imprimé)

2291-2436 (numérique)

Découvrir la revue

Citer cet article

Gallaugher, A. (1999). Articulations of Locality: Portraits and Narratives from the Toronto-Cuban Musicscape. Canadian University Music Review / Revue de musique des universités canadiennes, 19(2), 102-114.

https://doi.org/10.7202/1014451ar
Résumé de l'article

In keeping with a current movement in ethnomusicology and popular music studies concerned with musical constructions of space, time, and other, this paper presents a mini-ethnography of the Toronto-Cuban musicscape. Using as a point of departure Sara Cohen's statement that "We are all multiply placed with multiple identities but that does not necessarily mean that we are well-placed" (1995), the paper highlights some of the problems and discrepancies-i.e., the more negative, troublesome, and less coherent sides of placement-involved in the multiple and heterogeneous articulations of Cuban-ness within this locality.
All Rights Reserved @ Canadian University Music Society / Société de musique des universités canadiennes, 1999
Ce document est protégé par la loi sur le droit d'auteur. L'utilisation des services d'Érudit (y compris la reproduction) est assujettie à sa politique d'utilisation que vous pouvez consulter en ligne.

https://apropos.erudit.org/fr/usagers/politique-dutilisation/ 


\title{
ARTICULATIONS OF LOCALITY: PORTRAITS AND NARRATIVES FROM THE TORONTO-CUBAN MUSICSCAPE ${ }^{1}$
}

\author{
Annemarie Gallaugher
}

In her article "Localizing Sound," ethnomusicologist Sara Cohen states: "We are all multiply placed with multiple identities but that does not necessarily mean that we are well-placed."2 This idea of placement, both good and bad, underlies Cohen's notion of "locality" which she suggests might be used in popular music studies to imply two things: (1) "a methodological orientation that is concerned with the particular rather than the general, the concrete rather than the abstract;" and (2) "a particular relationship between the spatial, the social, and the conceptual." 3

Cohen's notion of locality is compelling for it raises the possibility that music be considered as a means of actually articulating "locality." However, it seems to me that Cohen's portrait of Jack-the concrete character whose narrative voice she uses to articulate a particular musical locality, namely, Liverpool Jewish-is perhaps too thickly drawn on the side where Jack feels a well-placed and secure identity through music and too thinly drawn on the side where he does not feel well-placed. Thus the methodology and the "particular relationship between the spatial, the social, and the conceptual" that Cohen represents through Jack, is, for me, overly bounded by a somewhat ethnically and individually too-tight coherence.

With Cohen's article in mind, the purpose of this paper is to extend ethnomusicological approaches to locality by investigating the ways in which the more negative, troublesome, and less coherent sides of placement-what Christopher Waterman might refer to as "alien spaces"-are articulated. ${ }^{4}$ For this purpose, I have gathered together as a sort of "mini-ethnography," a

1 I would like to thank the following members of the York University Music Department for their help with the preparation of this paper: Rob Bowman, Beverley Diamond, Will Echard, Brigido Galvan, Eduardo Lis, Michael Marcuzzi, James Robbins, and Robert Witmer. I would also like to thank all those who agreed to participate as interviewees. This paper is dedicated to the memory of Ada Perez.

2 Sara Cohen, "Localizing Sound," in Popular Music Style and Identity: International Association for the Study of Popular Music Seventh International Conference on Popular Music Studies, ed. Will Straw, Stacey Johnson, Rebecca Sullivan, and Paul Friedlander (Montreal: Centre for Research on Canadian Cultural Industries and Institutions, 1995), 66.

3 Ibid., 61.

4Christopher Waterman, "Music as Context: The Production of Locality in Diasporic Cultures," paper presented at the Fortieth Annual Meeting of the Society for Ethnomusicology, Los Angeles, October 1995. 
collection of portraits and narratives from a locality I refer to, following Slobin, as "the Toronto-Cuban musicscape." 5 Drawing from interviews, conversations, program notes, song texts, liner notes, and media reviews, as well as from my own experiences in Havana and Toronto, my methodology has been eclectic, including media and discourse analysis, co-listening activities, life stories, and participation as an audience member at a variety of Cuban music events.

The ethnographic details I present below have been selected with attention to a major concern current among a growing number of ethnomusicologists and popular music scholars. Although that concern has been spelled out by various authors in various forms, it might be generally summarized as a movement away from, to borrow Will Straw's terms, "an investment in imaginary unities." 6 This movement requires new and renewed questioning of concepts such as "community" and "ethnic identity." Further, it requires an expansion of research focus so that listeners, fans, and other consumers of music generally, are seen to have as significant and effective a place in the music-making, or "musicking," phenomenon as musicians, performers, and other sorts of music producers. ${ }^{7}$ Finally, it requires an examination of these identities in terms of the ambiguities of their relationships to one another; the particular and concrete relationships among "musickers" must be appreciated and understood not only at the points where they cohere spatially, socially, and conceptually within a locality, but also at the points where they conflict, and at all the shifting points of in-and-out-of-placeness in between.

In an attempt to fulfil some of these requirements, I have expanded my own research focus here to include a wider variety of voices than might conventionally be expected to appear in an ethnographic study of the Toronto-Cuban musicscape, i.e., people who are self-defined as "Cubans" and "musicians." Why have I incorporated these additional voices into my study? Because it seems to me that what is often forgotten in much of the ethnographic literature focusing on locality and the musical construction of space is the fact that (as Charles Keil recognizes in My Music and Music Grooves, for example) music counts on the participation ("participatory discrepancies" might be an even more apt term here) of non-musicians as much as on that of musicians. ${ }^{8}$ Further, in such cosmopolitan, culturally diverse, global centres as Toronto, most contemporary popular musics seemingly organized around a particular ethnic-

5Mark Slobin, "Micromusics of the West: A Comparative Approach," Ethnomusicology 36, no. 1 (1992): 1-87.

6Will Straw, "Systems of Articulation, Logics of Change: Communities and Scenes in Popular Music," Cultural Studies 5, no. 3 (1991): 368-88.

7Christopher Small, Music of the Common Tongue (London: Calder Publications; New York: Riverrun Press, 1994).

8 Susan D. Crafts, Daniel Cavicchi, Charles Keil and The Music in Daily Life Project, My Music (Hanover, N.H.: University Press of New England, 1993); Charles Keil and Steven Feld, Music Grooves (Chicago and London: University of Chicago Press, 1994). While Keil applies the term "participatory discrepancies" to strictly musical notions of time and groove, he also uses it in a broader sense with regard to worldview; thus its connection, for me, to notions of locality. 
ity or community also count on the presence of a variety of social and musical identities for the ways in which they are articulated, negotiated, and portrayed.

As I hope to demonstrate, when a greater range of participation in the musical locality is allowed for and when a greater range of voices is juxtaposed and interrelated in that locality, there is greater potential for revealing ambiguities, discrepancies, and otherwise hidden "alien spaces," for exposing the points of articulation where members of a locality do not feel "well-placed." My own shifting and ambivalent sense of placement/displacement within the Toronto-Cuban musicscape is perhaps a first case in point.

For me, as for many Anglo-Canadians, Cuba has long been a source of fascination. On social, political, and cultural levels, the struggles of this Caribbean/Latin-American island nation-state (particularly since the 1959 Revolution) to come to terms with issues of power and identity in a global context has indelibly marked that part of my consciousness inclined to seek a Canadian identity distinguishable from that of the United States. Already in childhood, Cuba had formed part of my Canadianness and had given me an early socio-political sense of where I belonged. Canada's policy of friendship provided a rare and secure place where the difference between Canada and the United States with its policy of embargo could be understood. Cuba also contributed greatly to my early musical identity, ironically so much so at times that I had no idea that what I was listening to as "my music" was, in fact, Cuban music. In some ways, then, and I do not think I am alone in this, I see Cuba as part of my identity. ${ }^{9}$

More recently, a number of influences and conditions have arisen to ensure my continued sense of identification with Cuba. With foreign policy decisions on constructive engagement and trade and business initiatives between the two countries, with increased recreational travel by Canadians to Cuba (an estimated one million Canadian tourists per year), with a growing Cuban population in Canada, "things Cuban" have been a focus of much popular media and community attention. Toronto, in particular, has been a site of this burgeoning interest, hosting various Cuban art shows, musical events, academic conferences, political delegations, and business seminars.

Yet as I have come to realize through greater first-hand experience of meeting people from Cuba both in Toronto and Havana, within this framework of heightened attention to Cuba, the voices and stories of Cubans themselves, and particularly Cubans living here, remain largely (albeit at times for reasons of political sensitivity) unheard and unappreciated. The media and other popular representations that do exist are most often third-person accounts, quite removed from the realities of the Cuban population in Toronto, and rife with assumptions and stereotypes. Among these assumptions and stereotypes,

9I realize that these comments are likely to be seen as controversial, perhaps particularly so for (1) anti-Castro Canadians and Cubans living here and elsewhere in the Cuban diaspora; (2) critics who would say that my sense of "Cubanness" is largely an American and not a Canadian construction; and (3) critics who insist on "us/them" or "self/other" dichotomies. 
I am thinking, for example, of the typically reduced media representations of Cuba as a legendary political ideology (representations which are now as frequently critical of this ideology as they are supportive), as a newly emerging business opportunity, or a fun vacation spot. I am also thinking of the representations by friends and acquaintances who visit the country frequently, staying with Cuban friends and families. For them, Cuba is a mythically enchanted magicland, a place where they can rediscover-especially through the perceived richness and "authenticity" of Cuban music-their lost spirituality or alienated sense of sociability.

Part of the problem is, of course, that once the actual voices and stories of Cubans themselves are heard, many of the "imaginary unities" behind such assumptions and stereotypes can no longer hold. While there may be several consequences to this, the ones that interest me most here are those involving the creation of musical and political ambiguities. In order to get at these discrepancies, of course, it is not enough to listen to Cuban voices in isolation only; they must be heard in the context of other voices who share a particular spatial, social, and conceptual relationship with them. When this approach is taken, new and often unexpected identities are differentiated and new and often problematic articulations of those identities emerge. The following collection of ethnographic texts is a set of richly articulated moments from the TorontoCuban musicscape. It is an exploratory, initial sampling of the particular and concrete first-person voices that have shifted my imagined identity with Cuba, thus troubling my sense of being well-placed within that identity. It is based on the notion that ambiguities of placement-whether they be manifested as open conflicts or more subtly as contrasts and clichés-can become especially apparent when music becomes the means of articulating locality. Like any of the representations pointed to above, the one here runs the risk of replacing one set of assumptions and stereotypes for another; like any ethnography, the claim it makes for being closer to the first-person is, of course, debatable.

As a point of entry into the problem of articulations of locality within the Toronto-Cuban musicscape, and as the first in the series of portraits and narrative voices around which this paper is structured, I would like to consider the Toronto-based Afro-Cuban Drum and Dance Ensemble, Ilédè. While the name, Ilédè, and the description "Afro-Cuban Drum and Dance Ensemble" might imply an all-Cuban group, Ilédè's members are actually from a mix of various Canadian and Cuban backgrounds. While ideally this should not be an issue, audiences often express a need to be able to distinguish between mixed groups, such as Ilédè, and so-called "authentic" Afro-Cuban ensembles like Los Munequitos de Matanzas who also, through recordings and periodic live performances, participate in the Toronto-Cuban musicscape. Audience reactions to this cross-cultural situation are often strong, ranging from disappointment-"Oh, they're not all Cuban!"-to amazement-"Wow! They're all Cuban!"-or, "Wow! They're not Cuban!" Here, then, is one of the first problems of articulations of locality for it raises the question of how musical 
labels and descriptions are seen to complement or contradict audience expectation.

For Ilédè, these problems also extend into the religious realm. Ilédè's repertoire draws heavily upon musics, dances, and drumming practices (as do many popular Cuban musics) associated with sacred rituals in the Santeria religious tradition. Yet these practices are presented in contexts that are decidedly secular. Or are they? Again, a question is raised about audience assumption and the surprise experienced by audience members not anticipating such strong linkages between, on the one hand, religion and Cuban music, and, on the other, between religion (particularly African-based religion) and the citizens of a communist state.

The following excerpt, taken from the program notes to a concert presented by Ilédè in 1995 at Toronto's du Maurier Theatre, points to some of the difficulties involved in trying to create locality.

For members of the [Santería] religious community here in Toronto, it has been extremely difficult to maintain these religious practices given the nature of daily life in Canada and transformation of their surroundings. We hope that this concert is a means by which the community here can re-establish itself and look for ways in which they can form closer bonds with one another. Among all of you here tonight are members of the religious community that you have not yet come to know - both of Cuban and Canadian heritage! We hope that tonight might be a starting point for meeting one another. For members of the Cuban community, believers and non-believers, I propose a few questions that perhaps you may take home with you this evening. There are very few among you, if any at all, who would call themselves rumberos yet is there one among you who does not know of the guaguancó? There are some of you who would not call themselves Santeros yet is there one among you who could not tell me of Shangó? Personal and cultural identities in their simplest forms defy definition yet at some level they are inextricably bound to what can be considered Cuban. ${ }^{10}$

As a quick application of basic discourse analysis to the above excerpt shows, we have the tensions of at least two different lexical sets operating here: one a lexis of, say, belonging - "hope/closer bonds/community/meeting/inextricably bound"-the other a lexis of not-belonging-"extremely difficult/transformation/the need to re-establish/not yet come to know/starting point/non-believers/questions/defy."

While the small but emerging Santería community in Toronto suggests that the religious articulation of locality is a potentially rich area of investigation for the study of Cuban music here, my immediate interest is with the last sentence of these program notes. To repeat: "Personal and cultural identities

10Iléde, Moyuba Orisha: Songs to the Orishas, program notes, 22 October 1995. "Santería" is an Afro-Cuban religious practice to which many Cuban musics are linked although this link remains largely unknown to Canadian listeners; rumberos are practitioners of the musical genre, rumba; guaguancó is one type of rumba; Santeros are practitioners of the religion; Shangó is an orisha or spiritual being. 
defy definition yet at some level they are inextricably bound to what can be considered Cuban."

As noted above, for me, as a child growing up in Canada, I already had some sense of this "inextricable boundedness." Then, the dominant image I had of "what could be considered Cuban" was largely socio-political. The Revolution, its promise of social equality, its resistance against U.S. hegemony, its attractive leader, all served in some youthful, idealistic way to mark my Canadianness. While I have a somewhat larger and more critical perspective now, stories about Cuba as a geopolitical entity are still very much a dominant image within the Canadian media. Yet, very rarely do we hear from Cubans themselves, particularly from Cubans who are now living here.

One Cuban who has managed to make his voice heard here is the singer and composer Luis Mario Ochoa who, with his band Cimarrón, released a debut $\mathrm{CD}$ in 1995. As Ochoa's liner notes to this CD explain:

Cimarrón, which means wild and untamed, was how the slave owners referred to their runaway slaves during Cuba's colonial era. But for me and many other Cubans living in exile, the word Cimarrón has come to define our status in the world, we are runaways searching for freedom. ${ }^{11}$

This theme is taken up especially in one of Luis Mario Ochoa's salsa-style compositions, "Soy Cimarrón." My rough translation of the original Spanish lyrics follows.

"Soy Cimarrón"
How are things in my country
Always I am asking
Thinking about my people
How they are doing
It is melancholy
That the immigrant feels
Dreaming about returning
Living in the present and the past
I left my homeland one day
Looking for freedom
I found it, but didn't abandon
My Cuban identity
I had to start from zero
But I had a mission
To take my song to a world
Without censure of opinion
Luis Ochoa, this is my name
I am satisfied to say
Cimarrón was my destiny
Freedom my conviction

11 Luis Mario Ochoa, liner notes to Luis Mario Ochoa and New Cimarron, A la Cubana, April 6 Productions, AP695 (1995). 
I will carry to the four winds

The message of my song

No one can now

Dictate what I sing

I am Cimarrón

I signify freedom. ${ }^{12}$

Because of the obvious concerns with identity and locality expressed in this song's lyrics, and because of the way it troubled my earlier political sensibilities, I decided to conduct several co-listening sessions with it. The first person I asked to participate in co-listening to "Soy Cimarrón" was a young Cuban woman in her late twenties who arrived in Toronto in 1994. She responded in writing as follows:

To Cubans, the term Cimarrón is synonymous to any act of rebellion in search for freedom and the most fundamental human rights. Cubans have been forced to resort to emigration after the dream of the Revolution turned out to be an aborted humanistic, political and social project, which has resulted in a profound disillusionment. I truly believe that, though fragmented and scattered as the Cuban community is here, the intrinsic message of "Soy Cimarron" is widely shared by its members. Simply put, we all feel that though we have left Cuba, Cuba has never left us. It dwells forever in our memory ...

As I listen to the song, I sense that eternal nostalgia, the agony in attempting to absorb an "other" culture, and the firm determination of not giving up our Cubanness ... It is a good reminder of my roots, of who I am and the importance of remaining as such. Identity is a big word these days, and we should all join forces to keep it alive. At times, when the feeling of loss and of not belonging seems harder than ever, it is the music of groups like Cimarrón that gives me inner strength and self-assurance. It is also a clear example of what humans can do in freedom, whatever their concrete interpretation of freedom happens to be. In the case of Cimarron-and I am paraphrasing the chorus-no one can any longer decide on what their songs should or should not say. The song is a good example of today's Cuban music. The rhythm and the lyrics are masterfully integrated with each other ... There are, naturally, incorporated elements of today's commercial salsa tunes whose presence is inevitable as these musicians are doing Cuban music in a nonCuban environment where most of what you are basically exposed to is commercialized music. ${ }^{13}$

This participant is not a musician but, as can be seen from her response, music is nevertheless an important articulation of identity and means of emplacement for her.

12Ochoa, "Soy Cimarron," Ibid. Used with permission of the author. Upon previewing this paper prior to publication, Luis Mario emphasized the need to continue the type of dialogue initiated by my collection of responses to his work, in order to close the unfortunate gaps that often separate musician intent and listener reception.

13 Submission to the author, 9 October 1996. 
The associations in her response with "freedom," "nostalgia," "the dream of the Revolution," "disillusionment," "fragmentation," "roots," "Cubanness," "loss," and "not belonging" were all echoed in the conversation I had with the second co-listening respondent, a Cuban in his late forties who now makes Toronto his home. However, his response (excerpted below) also contained some interesting contrasts. With regard to the choice of musical setting, this person felt the salsa-style to be somewhat "out-of-place," given the serious sentiment of the lyrics. But while he expressed a strong sense of identification with these lyrics, he also pointed out that "being Cuban" is not his only identity, stressing his frustration with constant requests to do Cuban things and to speak as a representative of "Cubanness;" his desire, it appears, is to participate more as a Canadian, and to participate in technology.

When I read the words, I had the sensation to cry. It made me put myself in the same position he [the song's narrator] is in. I read the lyrics before I listened to the music and I was surprised when I heard it ... You asked me about the way the music and lyrics support each other. I like the song very much, but I expected a more serious style, more like nueva trova ${ }^{14} \ldots$ But, you know, I don't always just listen to Cuban things. And I don't always just do Cuban things. People are always asking me to come to this or that Cuban party and, of course, I go, but I' $m$ here, I'm in a different country, I want to do the things people do in this country, like working at my computer, for example. ${ }^{15}$

A third take on "Soy Cimarrón" comes from a Latin American musician in his early thirties. What I see evidenced in these comments is an articulation of a political perspective which, while it is at one and the same time a shared "locality" for a number of Latin Americans and other left-leaning Canadians, is a remarkable departure from the two previous responses. As can be seen in these words, with their focus on industrialized and non-industrialized countries and their reference to the "anti-Cuban thing," there is a tremendous "alien space" which, rather ironically, may separate many Cubans here from the wider society, thus pressuring them to relive the themes of isolation and restricted freedom of expression rather than relieve them.

I don't understand. Luis Mario says in his liner notes he wants to "express his feelings and offer hope and inspiration to the Cubans dispersed around the world and to those who must tolerate oppression in their homeland." But if it weren't for what his homeland has given him musically he would never have been able to produce this $\mathrm{CD}$... A good question to ask him is whether he would have written the same lyrics if he were in, say, Buenos Aires, for example. It would be good to find out what Cuban musicians in non-industrialized nations are doing, to find out if in industrialized nations, in North America, if they're exploiting the anti-Cuban thing in a way they couldn't do

14Nueva trova is a type of Cuban music particularly associated with the Revolution and practiced by performers such as Silvio Rodriguez and Pablo Milanes.

15 Interview with the author, 10 October 1996, Toronto. 
in Argentina or other Latin American or European countries where a lot of people from the left would not like it. ${ }^{16}$

A further response to "Soy Cimarrón," yet with another interpretation of it, comes from a Canadian-born, non-musician. Despite her strong denial of my claims that she could be considered a member of the Toronto-Cuban musicscape, or my suggestion that part of her identity could be considered Cuban, this respondent not only joined me in listening to the $C D$ version of the song but also attended a live performance of it at a popular Toronto nightclub. I appreciated this respondent's comments for their directness, for I know from witnessing similar reactions among friends, students, nightclub audiences, and in the media here, that these nostalgic "Ricky Ricardo" associations are not merely idiosyncratic.

I don't have the jargon to talk about it because I'm not a musician, but I would like to know more about music, I would like to learn. But what appeals to me was the beat, the beat, I guess you'd call it. Why do I move constantly when I hear it? How can you not move? I need to, I need to move. It's moving me. But I will say one thing, I'm glad he changed his jacket. That red one was tacky. It was right out of the 50s. All I could think of was Ricky Ricardo. Unfortunately for him, in our culture, whenever people hear that music they want to yell "Babalu" and they expect Lucy to come right out. But, I can also see my Daddy doing the cha-cha, it would not have been a problem for him. But for me, I thought his presentation was a little old-fashioned. ${ }^{17}$

The words of a member of Orquesta Klave y Kongo, an all-Canadian-born son-rumba group acknowledge the difficulties with such "Ricky Ricardo" clichés.

It's a very real problem, a very deeply rooted problem. It's difficult for people to overcome these visual manifestations-and the sounds, too. In this sense, Cuban music is really "out of time" here and that's why it's not more popular in more places. It's difficult for people to get over this. ${ }^{18}$

It is also often difficult for Cuban performers here to appreciate how deeply Ricky Ricardo images and sounds have penetrated the Canadian musicscape

16 Interview with the author, 11 October 1996, Toronto.

17 Interview with the author, 19 October 1996, Toronto. In the live performance, Ochoa wore a bright red satin jacket. For the CD cover art, he has opted for a more conservative black and white double-breasted check, although he is portrayed against a backdrop of red satin. It is interesting to note this respondent's initial comment. In saying, "I don't have the jargon to talk about it," she points to an area of difficulty in the study of musical locality which I strongly think bears future examination: the apologetic insecurity, if not fear, that many Canadian non-musicians express when called upon to speak about music. Rarely have I encountered such hesitation among Cuban non-musicians. Is this difference explainable in terms of the stereotypical Canadian "inferiority complex"? Is it that, in Canada, music tends to be separated from daily life whereas in Cuba it is not? Is it that, because of the Revolution, music has been part of the Cuban people's consciousness for decades?

18 Interview with the author, 21 October, 1996, Toronto. 
and it is certainly hard to feel "well-placed" if your intent is, as Luis Mario has described his, to create "a very aggressive sound, a style with strong AfroCuban rhythms and a North American pop funk groove."

There is one final response to the "Soy Cimarrón" co-listening sessions that I conducted that I would like to mention here. It came from a Cuban musician in his early twenties who, as a polite indication of his unwillingness to participate in my study said, "I think music and politics should always be kept separate." In order to bring this voice out of isolation, and also in order to suggest that the Toronto-Cuban musicscape reaches across long distances, I include the following excerpt from an interview with the renowned bassist Israel "Cachao" Lopez which appeared in the magazine La Gaceta de Cuba. Although my respondent would have had to substitute his own instrument for the bass, I imagine his position would be similar to that contained in Cachao's last sentence.

Interviewer: And why did you leave Cuba?

Cachao: For artistic motivations, fundamentally. I wanted to work in another environment, to try other rhythms. Moreover, myself, I am not interested in politics, I never have been. When one finds truth in music, the only thing you want is to make music from morning till night and for me the only thing that has interested me in my life is this: to make music. Because of this, I have never talked about politics, nor do I like to do interviews: my language is the bass. ${ }^{19}$

One Canadian-born musician whose music and talk about music is significantly dedicated to Cuban sounds is Jane Bunnett. Bunnett has achieved a high profile in jazz circles at local, national, and international levels and has received extensive recognition for her aesthetic approach. The collection of media commentaries below demonstrate some of the ways in which this aesthetic approach (audible on such recordings as Spirits of Havana and Rendez-vous Brazil/Cuba, for example) ${ }^{20}$ has been described.

In contrast to the musical expressions of locality articulated by Luis Mario Ochoa's band Cimarrón, it might be said that Jane Bunnett's approach is to utilize the local as a means of formulating a transnational or global jazz style. And yet, as a newspaper article explains:

Bunnett is careful to not allow her interest and involvement in these diverse musics to create false impressions about what she's doing. Rather than fall prey to the increasing trend of musical globalization, Bunnett sees her work as part of an ongoing approach to music governed by deeper feelings of musical community and spirituality. ${ }^{21}$

19Leonardo Padura Fuentes, "Cachao: mi idioma es un contrabajo" [Cachoa: my language is the bass], La Gaceta de Cuba 5 (1994): 45 (translation from the Spanish by the author).

20Jane Bunnett, Spirits of Havana, Denon CAN 9011 (1992), Rendez-vous BrazilCuba, Justin Time, JUST 74-2 (1995).

21 Now, 5-11 January 1995, 30. 
In the same article, Bunnett herself is quoted as saying:

I would never want it to appear that I' $m$ dabbling in "world music," because that's not the intention ... As a jazz artist, that's where I am, and there's no way I could ever be a Cuban or African musician. I adhere more to the aesthetic of the 1960s avant-garde ... where there was a deep sense of spirituality within the music that managed to go beyond the boundaries and create music that attained so much more than just record sales. That's the most beautiful thing you can do. ${ }^{22}$

From the way my observations have been shaped above, it may appear that I am trying to remove all political implications from Jane Bunnett and thus elevate her to some transcendent, apolitical, global aesthetic realm while, at the same time, framing Luis Mario Ochoa and Cimarrón as musicians whose situation, whether or not they intend or desire it, is inevitably politically, rather than aesthetically, in the ascendant. However, this is not the narrative impression with which I want to end.

The political impact of Jane Bunnett's musical endeavours is integrally connected to the aesthetic one. The fact that she titled her latest North American tour with Afro-Cuban folkloric group Oba-Ilu, "The Helms or High Water Tour," 23 is an obvious marker of a political position.

As for Luis Mario Ochoa's aesthetics, he says (and I am paraphrasing here):

Jane has done a lot for Cuban music and Cuban musicians in Toronto and I like her music. But if you're asking me do I plan to incorporate other sounds into my music-no, I want to do something else. ${ }^{24}$

Ochoa then went on to tell me the story of how a journalist had once asked him a similar question about whether his future projects would include "global" sounds. In jest, he said that, "yes," he was planning a project which combined Irish and Cuban music. The problem is, the enthusiastic journalist-but I think he might as well have said the ethnomusicologist—did not realize it was a joke and printed the story the following day.

But where is the real punchline in this joke? The recent success of so-called world music groups such as Afro-Celtic Sound System suggest that a combined Irish-Cuban musical project may not be so far-fetched. What, then, is the basis for Luis Mario's rejection of this type of project? Conversely, what is the basis for his acceptance of North American pop funk? How is it that he hears "other sounds" in Jane Bunnett's music while the late Guillermo Barreto, producer of, and featured musician on, Spirits of Havana (which was recorded in Havana), is quoted as saying, "I couldn't believe she wasn't Cuban"?25

22 Ibid.

23Elizabeth Renzetti, "Bunnett's U.S. Tour Stalls," Globe and Mail, 11 September 1996, C1; referring to the U.S. Helms-Burton legislation which penalizes foreign companies doing business in Cuba.

24 Interview with the author, 16 October 1996, Toronto.

25Robert Palmer, liner notes, Spirits of Havana. 
These questions, as well as the many others which I hope this paper has raised, either directly or by implication, point to the need for ongoing research into the making and re-making of alliances that are "the crucial political processes within popular music." 26 As indicated by the portraits and narratives presented above, there is a range of ambiguity in the way that Cuban identity is articulated within the Toronto-Cuban musicscape that cannot be accounted for by simple "us/them" or "self/other" dichotomies. Neither can it be accounted for by outmoded and uniformity-dependent concepts such as "community" or "ethnicity," by the privileging of the production/performance side of musical culture, or by attention to only the good, coherent side of placement through music.

The concept of locality as I have tried to interpret it here has allowed me to break through at least some of these imaginary unities and to reveal a number of discrepancies, among them that: contrary to audience expectation at times, a Cuban name for a musical group does not necessarily guarantee the presence of any Cuban musicians within the group; the presentation of Cuban music within a secular context does not necessarily guarantee the absence of sacred or religious concerns; the political views of Cubans who emigrate to Canada are diverse rather than unified; not all Cubans who emigrate to Canada agree that they must keep their Cuban identity alive and may be frustrated with requests that they do so; Cuban and other Latin American identities in Toronto may be conflictive, particularly around issues of politics, thus re-creating problems of isolation and restricted freedom in a context that might be expected to be conducive to alliances; while immigrant Cubans may bring nostalgic longings for their homeland or for the promise of the Revolution to their listening experiences here, Canadians may carry 1950s clichés of Ricky Ricardo and mambo shirts, or, they may carry their own idealized version of the meaning of the Revolution for them as Canadians struggling to maintain an identity apart from the United States. All of these postures may serve in unfortunate ways to displace the intent of musicians. Even though some Cuban musicians participate in making music with political purposes, they may nevertheless claim that they never mix music and politics. Finally, as the case of Canadian-born jazz musician Jane Bunnett illustrates, discrepancies abound when issues of the relationship between jazz, Cuban music, and world music are raised.

\section{Abstract}

In keeping with a current movement in ethnomusicology and popular music studies concerned with musical constructions of space, time, and other, this paper presents a mini-ethnography of the Toronto-Cuban musicscape. Using as a point of departure Sara Cohen's statement that "We are all multiply placed 370.

26Straw, "Systems of Articulation, Logics of Change: Communities and Scenes in Popular Music," 
with multiple identities but that does not necessarily mean that we are wellplaced" (1995), the paper highlights some of the problems and discrepanciesi.e., the more negative, troublesome, and less coherent sides of placement-involved in the multiple and heterogeneous articulations of Cubanness within this locality. 